\title{
Effect of Extreme Weather Events on Mental Health: A Narrative Synthesis and Meta-Analysis for the UK
}

\author{
Joana Cruz ${ }^{1, *(\mathbb{C}, \text { Piran C. L. White }}{ }^{1,2} \mathbb{(}$, Andrew Bell $^{3}$ and Peter A. Coventry ${ }^{4}(\mathbb{C}$ \\ 1 Department of Environment and Geography, University of York, Wentworth Way, York YO10 5NG, UK; \\ piran.white@york.ac.uk \\ 2 Interdisciplinary Global Development Centre, University of York, York YO10 5DD, UK \\ 3 Centre for Mental Health, 90 London Road, London SE1 6LN, UK; andy.bell@centreformentalhealth.org.uk \\ 4 Department of Health Sciences, University of York, Heslington, York YO10 5DD, UK; \\ peter.coventry@york.ac.uk \\ * Correspondence: joana.cruz@york.ac.uk; Tel.: +44-190432-4786
}

Received: 9 October 2020; Accepted: 16 November 2020; Published: 19 November 2020

check for updates

\begin{abstract}
Extreme weather events are increasing in frequency and severity as a consequence of climate change and pose a significant threat to population mental health. This is the case even in temperate regions such as the United Kingdom (UK) where flooding and heat waves are forecast to become more common. We conducted a systematic review to quantify the prevalence and describe the causes of common mental health problems in populations exposed to extreme weather events in the UK. We searched Web of Science, EMBASE and PsycINFO for studies that measured the prevalence of depression, anxiety, and post-traumatic stress disorder (PTSD) in populations exposed to extreme weather events in the UK, published up to 12 December 2019. We included 17 studies, four of which were included in meta-analyses to determine the point prevalence of common mental health problems in the period within 12 months following extreme weather events. The point prevalence was $19.8 \%$ for anxiety ( $\mathrm{k}=4 ; n=1458 ; 95 \%$ CI 7.42 to 32.15$), 21.35 \%$ for depression ( $\mathrm{k}=4 ; n=1458$; 95\% CI 9.04 to 33.65) and 30.36\% for PTSD ( $\mathrm{k}=4 ; n=1359 ; 95 \%$ CI 11.68 to 49.05 ). Key factors that affected mental ill health in people exposed to flooding were water depth and absence of flood warnings. Displacement from home underscored the narratives associated with people's perceptions of the impact of flooding. The high prevalence of common mental health problems suggests that the prevention of mental ill health in populations at risk or exposed to extreme weather events should be a UK public health priority.
\end{abstract}

Keywords: anxiety; depression; flooding; heat wave; post-traumatic stress disorder; systematic review

\section{Introduction}

Anthropogenic changes to Earth's biophysical systems have already had potentially irreversible impacts on the environment that are detrimental to physical and mental health [1]. These impacts are especially visible with respect to climate change. Many of the mental health impacts of climate change are associated with extreme weather events such as tropical storms and hurricanes, heatwaves, drought and floods, which are increasing in frequency and severity worldwide [2,3], with forecasts indicating that this trend will continue for decades to come [4].

Direct exposure to extreme weather events such as hurricanes and flooding can lead to loss of life, but there are also enduring impacts on people's mental health. These include depression, anxiety and mood disorders, post-traumatic stress, sleep disruption and suicide [5-10]. Mental health disorders are the third leading cause of years lived with disability, with a prevalence of greater than $10 \%$ across all 21 countries in the Global Burden of Disease study [11]. As well as being responsible for 
high levels of disability, mental health problems have a profound impact on the economy. Globally, lost productivity associated with common mental health problems such as depression and anxiety is estimated at US $\$ 1$ trillion each year [12]. In the UK, mental health problems accounted for 17.5 million days lost to sickness absence in 2018, equivalent to $12.4 \%$ of all reasons for sickness absence [13]. Just considering England, in 2018, the economic and social costs of mental ill health was estimated to reach $£ 119$ billion/year [14]. Given the high personal, public health and economic burden, the need to reduce the prevalence of mental health problems is a global health priority.

There is increasing evidence that extreme weather conditions have an impact on mental health for people in the UK with those experiencing storm or flood damage to their home having poorer mental health (e.g. Ref. $[15,16])$. More frequent heavy winter rainfall and changes in land use are contributing to increased surface and fluvial flooding, with 1 in 6 properties now at risk [6]. Ongoing climate change means that such extreme weather-related conditions are likely to be more frequent in the UK in the future [17], and it is important to understand the potential impacts on mental health so that effective interventions to reduce these impacts can be developed.

In this paper, we present the results of a systematic review to quantify the prevalence of common mental health problems in populations exposed to extreme weather events in the UK. We have adopted a mixed-methods approach, by applying a qualitative (narrative synthesis) and a quantitative (meta-analysis) analyses, to capture findings about people's experiences and perceptions of extreme weather events to better understand how exposure to these events drive mental ill health. The work can help inform the UK health and environment policy agenda to bring about integrated solutions to prevent and reduce mental health problems in the presence of extreme weather events.

\section{Materials and Methods}

\subsection{Search Strategy and Selection Criteria}

The systematic review was reported in accordance with the Preferred Reporting Items for Systematic Review and Meta-analysis (PRISMA) guidelines [18] (see Table S1, Supplementary Materials). The study selection followed four steps: (1) All reference records were downloaded to EndNote X9.3.1 (Clarivate Analytics, Philadelphia, USA); (2) duplicates were deleted using the software function; (3) the titles and abstracts were screened for eligibility; and (4) the potentially eligible references' full text was evaluated. We conducted an integrated search for quantitative and mixed-methods peer-reviewed English language articles in three electronic databases: Web of Science, EMBASE and PsycINFO, from inception to 12 December 2019. The search strategy complied with PECO framework: Participants, Exposure, Comparator and Outcomes. The search strategy was a combination of setting (e.g., "England", "United Kingdom"), exposure (e.g., "flood", "heat wave", "climate change") and outcome ("mental health", "depression", "anxiety", "well-being"). For this review, we used the definition of "extreme event" in Stephenson et al. [19]: "( . . ) events that have extreme values of certain important meteorological variables. ( ... ) such as large amounts of precipitation (e.g., floods), high wind speeds (e.g., cyclones), high temperatures (e.g., heat waves), etc.". The full search strategy is shown in Table S2.

Studies were screened by one reviewer (J.C.) using the eligibility criteria described below. Where eligibility was unclear, a consensus meeting with two other reviewers (P.C.L.W. and P.C.) was held to decide on inclusion. Studies were included if they met the following criteria: (1) The extreme event had taken place in the United Kingdom; (2) The study covered common mental health problems as described in the tenth edition of the International Classification of Diseases (ICD-10) [20]; (3) Mental health outcomes were measured using validated self-report scale or checklist (e.g., Generalized Anxiety Disorder scale (GAD-2); Patient Health Questionnaire (PHQ-2) depression sub-scale; short-form PTSD checklist (PCL-6)). We excluded studies that were conference abstracts, reports, reviews, meta-analyses, letters, pilot studies or protocols. Studies that only reported qualitative data and did not identify the participant population using ICD-10 diagnostic categories were also excluded. 


\subsection{Data Extraction and Quality Assessment}

One reviewer (J.C.) extracted relevant data from eligible studies. The following information was extracted: authors' names, publication year, sample size, participants' age, gender and ethnicity, extreme climate event, location (year of event), months after the event, health outcome (e.g., anxiety, depression, post-traumatic stress disorder), health outcome assessment (e.g., Generalized Anxiety Disorder scale (GAD-2); Patient Health Questionnaire (PHQ-2) depression sub-scale; short-form PTSD checklist (PCL-6)), inclusion in meta-analysis $(\mathrm{Y} / \mathrm{N})$ and quality score $(0-8)$ [21]. We used the eight-item Loney Criteria [21] to assess the quality of the studies. The overall score ranges from zero to eight, with each item worth one point if it met the criteria.

\subsection{Narrative Synthesis and Meta-Analysis}

Drawing on guidance for syntheses to inform policy making and research prioritization, we used a narrative synthesis approach [22]. This approach offers an efficient and practicable means to include a qualitative description and maps of findings of included studies and identify common and emergent themes about people's experiences and perceptions about the relationship between exposure to extreme weather events and mental health. Narrative synthesis draws on the techniques of thematic analysis to categorize emergent and recurring themes within and between studies.

To quantify the point prevalence of common health problems among populations exposed to extreme weather events, we calculated an overall summary effects size by applying a fitted random effects model to each of our outcomes. To quantify the observed variability between studies, we calculated $\mathrm{I}^{2}$ [23], the standard deviation $\tau(\mathrm{tau})$ and variance of heterogeneity $\tau^{2}$ [24]. $\mathrm{I}^{2}$ allows us to compare estimates of heterogeneity across meta-analyses; values of $50 \%$ represent moderate heterogeneity and values above $75 \%$ represent high heterogeneity [23]. $\tau^{2}$ is the total amount of systematic differences in effects across studies [24]. All results were plotted as forest plots with $95 \%$ confidence intervals. We divided the studies into two time frames according to time after the respondent had their house flooded: $\leq 12$ months and $>12$ months. Due to the reduced number of papers (1-2 studies depending on the mental morbidity), we only used in the meta-analysis and forest plots the references for $\leq 12$ months.

We identified influencing outliers by screening for externally studentized residuals that are larger than 2 in absolute value. If one or more studies were identified as outliers, we then assessed if they were truly influential by applying a leave one out sensitivity analysis [24]. Funnel plot and Eggers' regression test were used to evaluate potential publication bias. Statistical analyses were performed using the "meta" and "metafor" package of R version 3.6.2 (R Foundation for Statistical Computing, Vienna, Austria) [25].

\section{Results}

\subsection{Study Selection}

The database search initially identified 1667 studies, from which 194 duplicates were removed. After title and abstract screening, 1311 ineligible studies were excluded. A total of 166 potentially relevant full-text studies were independently assessed based on the selection criteria. From these, 149 studies were excluded for the following reasons: not related to extreme climatic events and/or wellbeing and mental health $(n=107)$; review studies $(n=8)$; qualitative data only $(n=8)$; conference proceedings; poster or book section $(n=6)$; no health outcome assessment scale identified $(n=5)$; no access to the paper $(n=5)$; study did not cover UK flood-affected populations $(n=4)$; not in English language $(n=1)$; data duplicated in another paper $(n=1)$; and not related to humans $(n=1)$. Seventeen studies were included in the systematic review and four studies were included in the meta-analysis (Figure 1). Only one study into heat waves was selected by applying this methodology. 


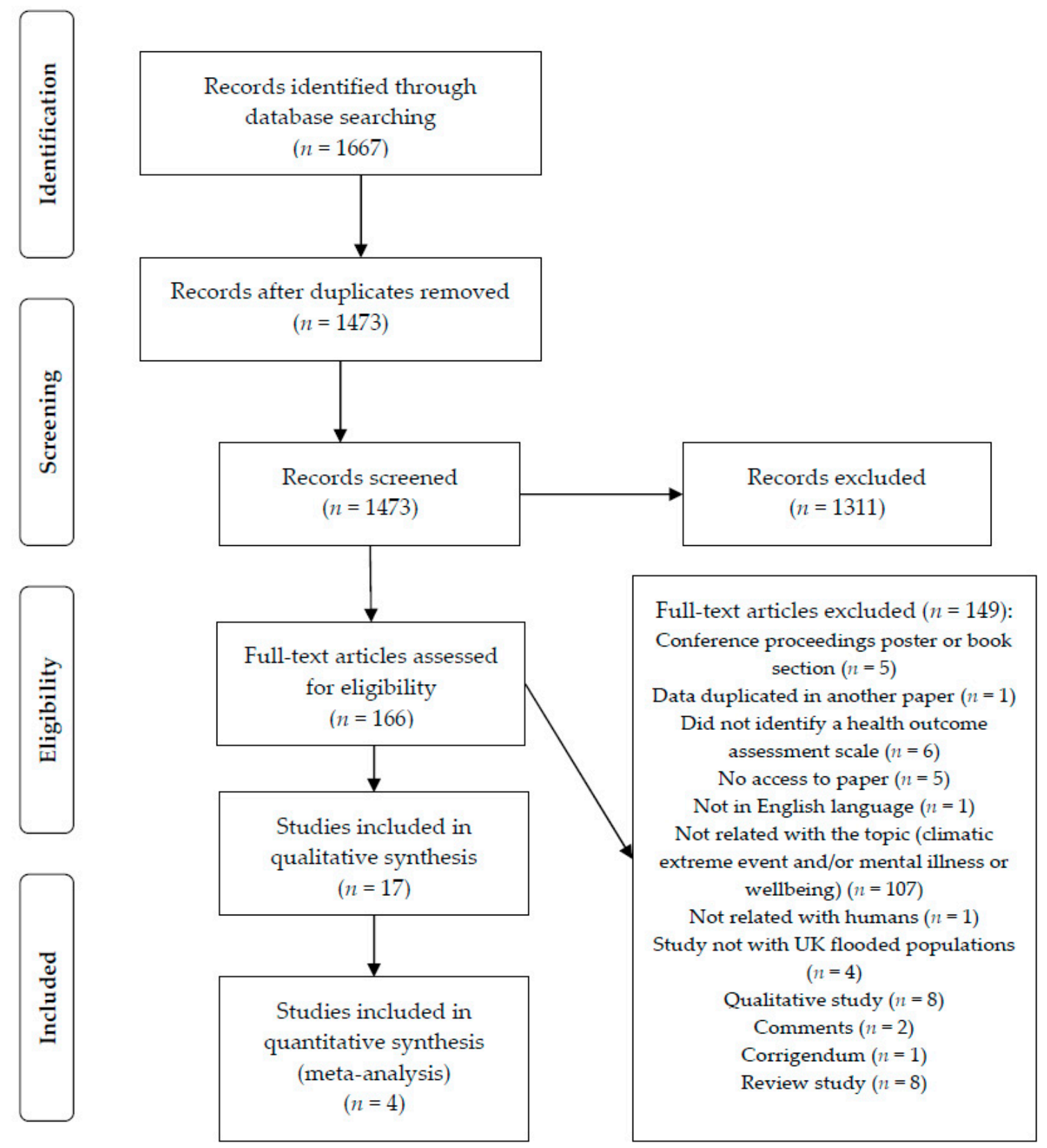

Figure 1. Preferred Reporting Items for Systematic Reviews and Meta-Analyses (PRISMA) flow chart of study identification process.

\subsection{Study Characteristics}

The 17 included studies reported extreme climate weather events related to floods and heat waves with an impact on a range of mental health outcomes: anxiety, depression, post-traumatic disorder syndrome (PTSD), psychological distress and suicide ideation.

Quality scores ranged from three to seven points across studies. The minimum quality score of three was recorded for two studies and a quality score of seven was recorded for three studies (Table 1). Two studies were scored four points, five were scored five points, and five were scored six points (Table 1). 
Table 1. Characteristics of the studies included in the narrative review and meta-analysis of the impact of floods and heat waves in mental health outcomes and wellbeing.

\begin{tabular}{|c|c|c|c|c|c|c|c|c|}
\hline Study & Event & $\begin{array}{l}\text { Location (Year of } \\
\text { Event) }\end{array}$ & Months after the Event & Respondents' Characteristics & Health Outcome & $\begin{array}{c}\text { Health Outcome } \\
\text { Measurement }\end{array}$ & $\begin{array}{c}\text { Included in } \\
\text { Meta-Analysis (Y/N) }\end{array}$ & $\begin{array}{c}\text { Quality Score } \\
\quad(0-8)\end{array}$ \\
\hline French et al. [26] & Flood & Cumbria (2015/16) & 6 & $\begin{array}{c}\text { Flooded: } 119 ; \\
\text { Gender: } 59 \% ; \\
\text { Ethnicity: } 100 \% \text { white; } \\
\text { Marital status: } 64 \% \text { married/civil partners } \\
\text { or cohabiting; } \\
\text { Housing tenure: } 82 \% \text { owned house; } \\
\text { Employment: } 52 \% \text { employed and } \\
40 \% \text { retired; } \\
\text { Education level: } 45 \% \text { with degree or } \\
\text { above, } 32 \% \text { below degree; } \\
\text { English deprivation quintile: } 1.7 \% \text { in least } \\
\text { deprived quintile; } 6 \% \text { in quintile } 4 \text { and } 5 \\
\text { (most deprived); } \\
\text { Long-term illness: } 72 \% \text { yes }\end{array}$ & $\begin{array}{c}\text { Depression; } \\
\text { Anxiety; } \\
\text { Post-traumatic stress } \\
\text { disorder (PTSD); } \\
\text { Health-related } \\
\text { quality of life }\end{array}$ & $\begin{array}{c}\text { Patient } \\
\text { Health Questionnaire } \\
\text { (PHQ-2) depression } \\
\text { sub-scale; } \\
\text { Generalized Anxiety } \\
\text { Disorder } \\
\text { scale (GAD-2); } \\
\text { short-form } \\
\text { PTSD checklist (PCL-6); } \\
\text { 5 level EQ-5D } \\
\text { (EQ-5D-5L) }\end{array}$ & Y & 5 \\
\hline Graham et al. [15] & Flood & England (2013/2014) & 6 & $\begin{array}{c}\text { Flooded: } 354 ; \\
\text { Age: } 26 \% \text { aged } 16-34,39 \% \text { aged } 35-54 ; \\
27 \% \text { aged } 55-74 \text { and } 8 \% 75+; \\
\text { Ethnicity: } 89 \% \text { white, } 1 \% \text { black, } 7 \% \text { Asian; } \\
\text { Education level: } 31 \% \text { with degree, 14\% } \\
\text { teaching, HND and nursing, } 14 \% \% \text { A level, } \\
26 \% \text { GCSE or equivalent, } 13 \% \\
\text { no qualifications; } \\
\text { Housing tenure: } 76 \% \text { owned house; } \\
\text { Employment: } 69 \% \text { employed, } 28 \% \\
\text { economically inactive and } \\
\text { 3\% unemployed; } \\
\text { English deprivation quintile: } 29 \% \text { in least } \\
\text { deprived quintile, 34\% in quintile } 4 \text { and } 5 \\
\text { (most deprived) }\end{array}$ & $\begin{array}{c}\text { Depression; } \\
\text { Anxiety; } \\
\text { Obsessive compulsive } \\
\text { disorder; } \\
\text { Panic disorder; Phobias; } \\
\text { PTSD; } \\
\text { Suicide ideation }\end{array}$ & $\begin{array}{c}\text { Clinical Interview } \\
\text { Schedule-Revised } \\
\text { (CIS-R); } \\
\text { PTSD Checklist Civilian } \\
\text { Version (PCL-C) }\end{array}$ & Y & 7 \\
\hline Mason et al. [16] & Flood & Anonymized & 6 & $\begin{array}{l}\text { Gender: } 182 \text { males and } 262 \text { females; } \\
\text { Mean Age: } 57 \text { years }(S D= \pm 15 \text { years); } \\
\text { Employment: } 46 \% \text { employed, } 0.9 \% \\
\text { unemployed and } 33.6 \% \text { retired }\end{array}$ & $\begin{array}{l}\text { Depression; } \\
\text { Anxiety; } \\
\text { PTSD; }\end{array}$ & $\begin{array}{l}\text { Hopkins Symptoms } \\
\text { Checklist; } \\
\text { Harvard Trauma } \\
\text { Questionnaire }\end{array}$ & Y & 6 \\
\hline
\end{tabular}


Table 1. Cont

\begin{tabular}{|c|c|c|c|c|c|c|c|c|}
\hline Study & Event & $\begin{array}{l}\text { Location (Year of } \\
\text { Event) }\end{array}$ & Months after the Event & Respondents' Characteristics & Health Outcome & $\begin{array}{l}\text { Health Outcome } \\
\text { Measurement }\end{array}$ & $\begin{array}{c}\text { Included in } \\
\text { Meta-Analysis (Y/N) }\end{array}$ & $\begin{array}{c}\text { Quality Score } \\
(0-8)\end{array}$ \\
\hline Munro et al. [27] & Flood & $\begin{array}{c}\text { Counties of } \\
\text { Gloucestershire, } \\
\text { Wiltshire, Surrey, } \\
\text { Somerset, and Kent } \\
(2013 / 2014)\end{array}$ & 12 & $\begin{array}{c}\text { Flooded: } 605 \\
\text { Age: } 6.3 \% \text { aged 18-35, } 54 \% 36-64 ; 28.8 \% \\
\text { aged } 65-79 \text { and } 8 \% 80+; \\
\text { Marital status: } 69.3 \% \text { married/civil } \\
\text { partners or cohabiting; } \\
\text { Housing tenure: } 90.4 \% \text { owned house; } \\
\text { Employment: } 49.8 \% \text { employed and } \\
3.8 \% \text { retired; } \\
\text { Education level: } 37.0 \% \text { with degree or } \\
\text { above, } 39.2 \% \text { below degree; } \\
\text { English deprivation quintile: } 26.2 \% \text { in } \\
\text { least deprived quintile; } 2.6 \% \text { in } \\
\text { quintile } 4 \text { and } 5 \text { (most deprived); } \\
\text { Long-term illness: } 22 \% \text { yes }\end{array}$ & $\begin{array}{l}\text { Depression; } \\
\text { Anxiety; } \\
\text { PTSD }\end{array}$ & $\begin{array}{c}\text { Patient } \\
\text { Health Questionnaire } \\
\text { (PHQ-2) depression } \\
\text { sub-scale; } \\
\text { Generalized Anxiety } \\
\text { Disorder } \\
\text { scale (GAD-2); } \\
\text { short-form } \\
\text { PTSD checklist (PCL-6) }\end{array}$ & $\mathrm{Y}$ & 6 \\
\hline Jermacane et al. [28] & Flood & England (2013/2014) & 24 & Flooded: 339 & $\begin{array}{l}\text { Anxiety; } \\
\text { Depression; } \\
\text { PTSD }\end{array}$ & $\begin{array}{c}\text { Patient } \\
\text { Health Questionnaire } \\
\text { (PHQ-2) depression } \\
\text { sub-scale; } \\
\text { Generalized Anxiety } \\
\text { Disorder } \\
\text { scale (GAD-2); } \\
\text { short-form } \\
\text { PTSD checklist (PCL-6) }\end{array}$ & $\mathrm{N}$ & 6 \\
\hline Tunstall et al. [29] & Flood & $\begin{array}{c}\text { England and Wales } \\
\text { (1998) }\end{array}$ & 60 & Flooded: 982 respondents & $\begin{array}{c}\text { Anxiety; } \\
\text { Depression; } \\
\text { PTSD; } \\
\text { Psychological distress; } \\
\text { Suicide ideation }\end{array}$ & $\begin{array}{c}\text { General Health } \\
\text { Questionnaire } \\
\text { (GHQ-12); } \\
\text { Post-Traumatic Stress } \\
\text { Scale (PTSS) }\end{array}$ & $\mathrm{N}$ & 5 \\
\hline Reacher et al. [30] & Flood & Lewes (2000) & 9 & $\begin{array}{c}\text { Flooded: 227; } \\
\text { Gender: } 123 \text { females; } \\
\text { Age: } 22 \% \text { aged 0-17, 24\% 18-39; } 17 \% \text { aged } \\
40-49,22 \% \text { aged } 50-64 \text { and } 15 \% \text { 65+ }\end{array}$ & Psychological distress & $\begin{array}{l}\text { General Health } \\
\text { Questionnaire } \\
\text { (GHQ-12) }\end{array}$ & $\mathrm{N}$ & 7 \\
\hline $\begin{array}{l}\text { Paranjothy et al. } \\
\text { [31] }\end{array}$ & Flood & $\begin{array}{l}\text { South Yorkshire and } \\
\text { Worcestershire (2007) }\end{array}$ & $\begin{array}{l}\text { South Yorkshire: } 3 \\
\text { Worcestershire: } 6\end{array}$ & $\begin{array}{l}\text { Gender: } 72 \% \text { females in South Yorkshire } \\
\text { and } 57 \% \text { females in Worcestershire; } \\
\text { Mean age: } 50 \text { years }(\mathrm{SD}= \pm 17 \text { years) in } \\
\text { South Yorkshire and } 57 \text { years (SD }= \pm 17 \\
\text { years) in Worcestershire; } \\
\text { Employment: } 28 \% \text { unemployed and } 24 \% \\
\text { retired in South Yorkshire; and } 39 \% \\
\text { unemployed and 9\% retired in } \\
\text { Worcestershire }\end{array}$ & $\begin{array}{c}\text { Depression; } \\
\text { Anxiety; } \\
\text { PTSD; } \\
\text { Psychological distress }\end{array}$ & $\begin{array}{c}\text { Patient } \\
\text { Health Questionnaire } \\
\text { (PHQ-9) depression } \\
\text { sub-scale; } \\
\text { Generalized Anxiety } \\
\text { Disorder } \\
\text { scale (GAD-7); } \\
\text { short-form } \\
\text { PTSD checklist (PCL-6); } \\
\text { General Health } \\
\text { Questionnaire } \\
\text { (GHQ-12) }\end{array}$ & $\mathrm{N}$ & 6 \\
\hline
\end{tabular}


Table 1. Cont.

\begin{tabular}{|c|c|c|c|c|c|c|c|c|}
\hline Study & Event & $\begin{array}{l}\text { Location (Year of } \\
\text { Event) }\end{array}$ & Months after the Event & Respondents' Characteristics & Health Outcome & $\begin{array}{l}\text { Health Outcome } \\
\text { Measurement }\end{array}$ & $\begin{array}{c}\text { Included in } \\
\text { Meta-Analysis (Y/N) }\end{array}$ & $\begin{array}{l}\text { Quality Score } \\
\qquad(0-8)\end{array}$ \\
\hline Tempest et al. [32] & Flood & Anonymized (2013/2014) & 12 & Flooded: 622 & $\begin{array}{l}\text { Depression; } \\
\text { Anxiety; } \\
\text { PTSD }\end{array}$ & $\begin{array}{c}\text { Patient } \\
\text { Health Questionnaire } \\
\text { (PHQ-2) depression } \\
\text { sub-scale; } \\
\text { Generalized Anxiety } \\
\text { Disorder } \\
\text { scale (GAD-2); } \\
\text { short-form } \\
\text { PTSD checklist (PCL-6); }\end{array}$ & $\mathrm{N}$ & 6 \\
\hline Waite et al. [33] & Flood & $\begin{array}{c}\text { Counties of } \\
\text { Gloucestershire, } \\
\text { Wiltshire, Surrey, } \\
\text { Sedgemoor, South } \\
\text { Somerset, and } \\
\text { Tonbridge and Malling } \\
\text { (2013/2014) }\end{array}$ & 12 & Collected but not provided & $\begin{array}{l}\text { Depression; } \\
\text { Anxiety; } \\
\text { PTSD }\end{array}$ & $\begin{array}{c}\text { Patient } \\
\text { Health Questionnaire } \\
\text { (PHQ-2) depression } \\
\text { sub-scale; } \\
\text { Generalized Anxiety } \\
\text { Disorder } \\
\text { scale (GAD-2); } \\
\text { short-form } \\
\text { PTSD checklist (PCL-6); }\end{array}$ & $\mathrm{N}$ & 5 \\
\hline Greene et al. [34] & Flood & $\begin{array}{l}\text { South Yorkshire and } \\
\text { Worcestershire (2007) }\end{array}$ & $1-7$ & $\begin{array}{c}2029 \text { responders (flooded and unaffected); } \\
\text { Mean Age: } \\
\text { South Yorkshire: } 50 \text { years }(\mathrm{SD}= \pm 17 \\
\text { years), } \\
\text { Worcestershire: } 57 \text { years } \\
\text { (SD = } \pm 17 \text { years) }\end{array}$ & Psychological distress & $\begin{array}{l}\text { General Health } \\
\text { Questionnaire } \\
\text { (GHQ-12) }\end{array}$ & $\mathrm{N}$ & 5 \\
\hline Bennet [35] & Flood & Bristol (1968) & 12 & Flooded: 88 males and 109 females & Psychiatric complaints & Self-reported & $\mathrm{N}$ & 3 \\
\hline $\begin{array}{l}\text { Tapsell and Tunstall } \\
\text { [36] }\end{array}$ & Flood & $\begin{array}{c}\text { Banbury and } \\
\text { Kidlington (1998) }\end{array}$ & $\begin{array}{l}7 ; \\
12 ; \\
54\end{array}$ & Gender: 11 males and 21 females & $\begin{array}{c}\text { Anxiety; } \\
\text { Depression; } \\
\text { Suicide ideation; } \\
\text { Psychological distress } \\
\end{array}$ & $\begin{array}{l}\text { General Health } \\
\text { Questionnaire } \\
\text { (GHQ-12) }\end{array}$ & $\mathrm{N}$ & 4 \\
\hline $\begin{array}{l}\text { Akerkar and } \\
\text { Fordham [37] }\end{array}$ & Flood & $\begin{array}{l}\text { Tewkesbury (2007) } \\
\text { Morpeth (2008) }\end{array}$ & $\begin{array}{l}\text { Tewkesbury: } 18 \\
\text { Morpeth: } 12\end{array}$ & $\begin{array}{l}\text { Gender: } \\
\text { Tewkesbury: } 60 \text { males and } 76 \text { females; } \\
\text { Morpeth: } 90 \text { males and } 146 \text { females }\end{array}$ & Wellbeing & $\begin{array}{c}\text { Mental Health } \\
\text { Inventory (MHI-5); } \\
\text { SF-12 Patient } \\
\text { Questionnaire (SF-12) } \\
\end{array}$ & $\mathrm{N}$ & 3 \\
\hline $\begin{array}{l}\text { Wind and Komproe } \\
{[38]}\end{array}$ & Flood & Morpeth (2008) & 12 & $\begin{array}{c}\text { Flooded: } 231 ; \\
\text { Gender: } 61 \% \text { females; } \\
\text { Age: } 2.7 \% \text { aged } 18-24,9 \% \text { aged } 25-39, \\
\text { 42.6\% aged } 40-64 \text { and } 57.4 \% \text { 65+; } \\
\text { Marital status: } 38.4 \% \text { married/civil } \\
\text { partners or cohabiting; } \\
\text { Housing tenure: } 90.4 \% \text { owned house; } \\
\text { Employment: } 32.3 \% \text { employed and } \\
\text { 57.3\% retired; } \\
\text { Education level: } 22 \% \text { with degree or above }\end{array}$ & PTSD & $\begin{array}{l}\text { PTSD Checklist Civilian } \\
\text { Version (PCL-C) }\end{array}$ & $\mathrm{N}$ & 5 \\
\hline Milojevic et al. [39] & Flood & England (2011/2014) & $\mathrm{NA}$ & $\mathrm{NA}$ & Depression & $\begin{array}{c}\text { Number of } \\
\text { antidepressants } \\
\text { prescribed }\end{array}$ & $\mathrm{N}$ & 4 \\
\hline Page et al. [40] & Heat wave & $\begin{array}{l}\text { England and Wales } \\
\text { (1995 and 2003) }\end{array}$ & & & Suicide & Suicide counts & $\mathrm{N}$ & 7 \\
\hline
\end{tabular}




\subsection{Narrative Analysis}

Six themes were identified in the narrative and systematic review of the papers related to flooding and its impact on mental health and wellbeing: mental health morbidity; physical health and longer term effects on mental health; characteristics of the flood (e.g., increase in water depth); flood warning; displacement and loss of sense of place; and socio-economic impact. The impact of heat waves on mental health will not be analyzed in this and the following sections due to having only a single paper to report on.

\subsubsection{Mental Health Morbidity}

The majority of studies described anxiety, depression, PTSD, suicide ideation and psychological distress as the main mental health morbidities reported by respondents as a consequence of the flood event $[15,16,26-29,31-34,36]$. There was no report in any of the references on the mental health condition of the respondents prior to the event.

\subsubsection{Physical Health and Long-Lasting Impacts on Mental Health}

Alongside mental health problems, study participants also reported that they were affected by physical illnesses (e.g., earache, rash, gastroenteritis) [29,30,36,41,42]. Water quality and possible contamination of flood water with pollutants and water-borne pathogens were identified as factors that exacerbated existing psychological distress [29-31,36].

The long-lasting effect of flooding, from 6 to 24 months after the event, was described in several studies of flooded communities. This was illustrated by increased visits to GP practices and hospital referrals 12 months after the flood [35], and by participants self-reporting on-going psychological distress $[28-30,33,35,36]$. The risk of long-term mental health problems was reported to be between four [30] to 8.7 times [28] as high for flood victims compared with non-flooded subjects. Even years after the event, respondents affected by flooding experienced anxiety during heavy rain $[29,36,41,43,44]$. Anxiety was associated with increased levels of stress, sleep problems, panic attacks, difficulty concentrating on everyday tasks, lethargy, nightmares, anger, mood swings and increased use of alcohol or prescription drugs $[36,41]$ or antidepressants [39].

\subsubsection{Characteristics of the Flood}

Water depth in the house was associated with increased risk of psychological distress [27,29-31,33,34] and an increased number of attendances at GP surgeries [35]. Repeated flooding affected individuals differently: some presented increased symptoms of PTSD and anxiety [16], whilst others reported the same increased odds of psychological morbidity if exposed to a single event or repeated ones [26].

\subsubsection{Flood Warnings}

The absence of flood warnings contributed to a significant higher score for anxiety and PTSD than a warning of $12 \mathrm{~h}$ or more $[27,29]$.

\subsubsection{Displacement and Loss of Sense of Place}

The majority of studies reported that evacuation and temporary rehousing increased the rate of psychological distress [27,31], anxiety [16,27,33], depression [16,27,33] and PTSD [16,27,29,33]. One study, covering the population of Lewes, described no impact in these mental illnesses [30]. Alongside displacement, disruption of essential services (e.g., gas, electricity and water supply) $[31,33]$ as well as health or social services, and work or education, there were also increased odds of psychological morbidity [33]. The length of time to get the house back to normal were associated with an increased risk of psychological distress [36,42]. The odds ratio of anxiety, depression and PTSD were not related with the duration of displacement, being twice as likely for a flooded respondent to 
experience those conditions when they were either one or six months displaced [27]. Respondents that reported persistent flood damage to their property were more likely to suffer from depression and anxiety than flood respondents who did not suffer persistent damage $[28,33]$.

People reported a loss of sense of place and security and the grief of losing objects that make a home $[32,36,37,41,42]$. Within the family context, while there were respondents who experienced a positive change in their interpersonal relations (e.g., increased bonding), others found that relationships became stressful, leading to an increase in arguments $[32,37]$ and in some cases, to divorce [37]. At the community level, some studies reported a negative impact, with disrupted activities and loss of community spirit $[32,36]$, while others reported increased community resilience and reduced psychological distress owing to social cohesion and collective efficacy to combat the effects of the floods $[34,37,38]$.

\subsubsection{Demographic and Socio-Economic Profile of Flood Impact}

The majority of studies showed that women were more likely to report psychological distress and PTSD from having their home flooded then men [15,29,31,32,35-37]; only one study presented similar odds of psychological distress between genders [32]. Within women respondents, ethnic minorities (Pakistani respondents) were at a higher risk of those conditions than non-Pakistani respondents [36]. Possible explanations put forward for this difference were related to women's vulnerable social position, childcare responsibilities, usually with large families, lack of flooding experience and disbelief that these extreme events could happen in England [36]. A few studies described a different outcome: after the 1968 flood event in Bristol, there was a significant increase in male attendances to GP practices compared with before the floods [35]. A single study showed no significant difference by gender in recovery after the floods [37], while reporting that a higher percentage of women than men felt traumatized and experienced the floods as "very severe" [37]. Regarding age, respondents under 65 years reported higher levels of psychological distress than those of 65 years and over $[15,29,36]$.

Secondary stressors affecting mental illnesses differed between men and women [32]. For women, those with concerns about pets and being separated from their family were at a high risk of self-diagnosing with anxiety and PTSD. For men, those who reported relationship problems were most likely to experience depression and anxiety [32].

Home ownership, as an indicator of income, was linked to lower levels of poor mental health when compared with those in rented accommodation [15,29]. Those with lower income levels [15,41], unemployed [31], economically inactive [15] and those with prior medical conditions $[16,29,31]$ were more likely to experience deteriorations in their psychological health after exposure to flooding.

Other financial factors, such as problems with insurance companies or a lack of insurance, were associated with increased levels of stress immediately after flooding [29,36]. Lack of support from different authorities before, during and after the floods, which led consequently to a loss of confidence and trust, was also highlighted by the flood victims as hindering their mental recovery and increasing their levels of anxiety [36].

\subsection{Meta-Analysis of the Prevalence of Common Mental Health Problems}

All the surveys considered in the meta-analysis occurred $\leq 12$ months after the respondents experienced their house being flooded. The included studies reported prevalence rates of between $5.9 \%$ and $27.9 \%$ for anxiety, $7.1 \%$ and $34.6 \%$ for depression and $7.06 \%$ and $43.7 \%$ for PTSD. For all three conditions, the lowest prevalence rate was reported by Graham et al. [15]

The overall point prevalence rate for anxiety associated with flooding was 19.8\% (95\% confidence interval (CI): 7.4-32.2\%) (Figure 2). There was a high and significant heterogeneity in effect sizes between studies for anxiety: $\mathrm{I}^{2}=98 \%, \tau^{2}=0.02, \mathrm{Q}_{\text {resid }}(3)=120.5, p<0.0001$ (Figure 2). 


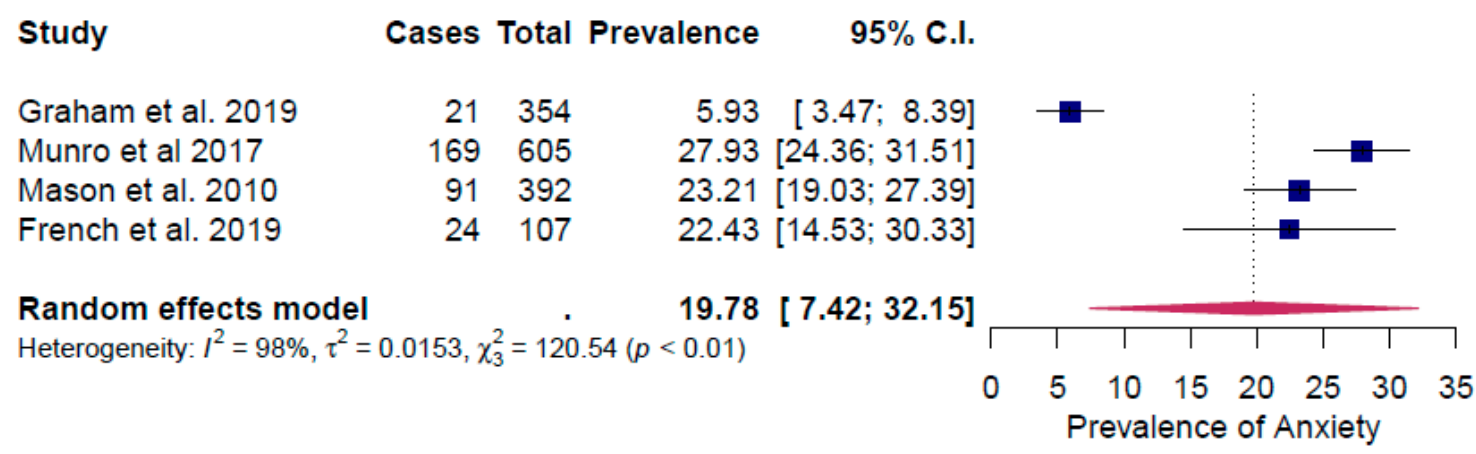

Figure 2. Forest plot of the prevalence rate of anxiety.

The results from the sensitivity analysis identified the study by Graham et al. [15] as an outlier, having a significant influence on the effect size (Figure S1). By removing that study, the prevalence of anxiety was $25.2 \%$ and the effect size heterogeneity decreased significantly $\left(\mathrm{I}^{2}=45 \%, \tau^{2}=0.0005\right.$, $\left.\mathrm{Q}_{\text {resid }}(2)=3.5, p=0.2\right)$.

For depression, the aggregated value for prevalence rate for depression was $21.3 \%$ (95\% confidence interval (CI): 9.0-33.7\%) (Figure 3). There was a high and significant heterogeneity in effect sizes between studies for depression: $\mathrm{I}^{2}=97 \%, \tau^{2}=0.02, \mathrm{Q}_{\text {resid }}(3)=114.3, p<0.01$ (Figure 3).

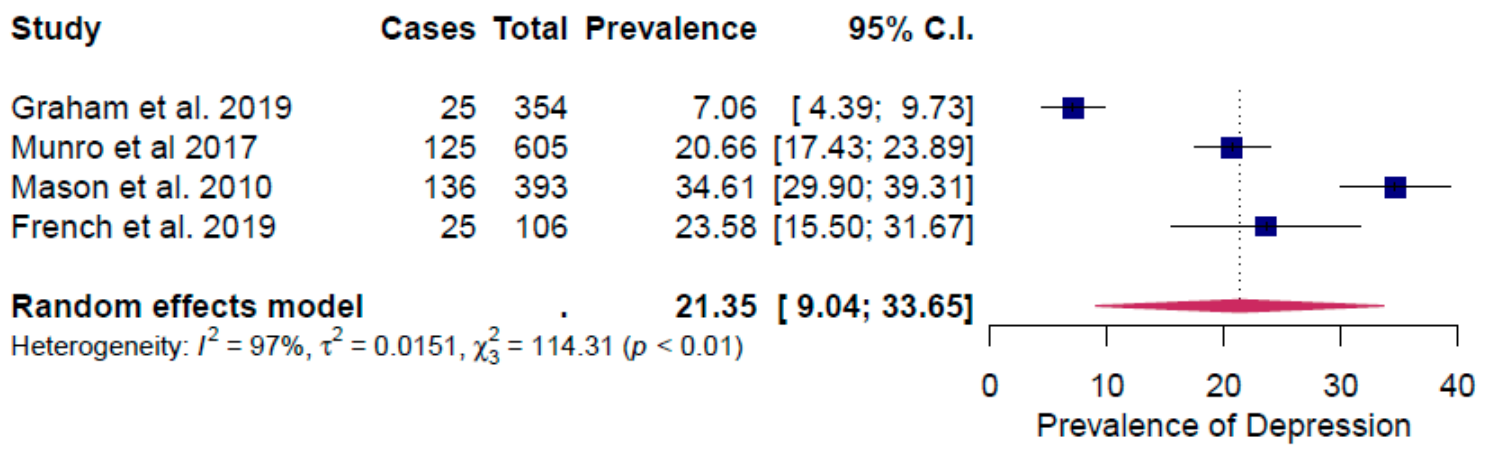

Figure 3. Forest plot of the prevalence rate of depression.

The leave one out sensitivity analysis identified two studies as having a significant influence on the effect size (Figure S2)—Graham et al. [15] and Mason et al. [16]. By removing Graham et al. [15], the prevalence of depression increased to $26.3 \%$; heterogeneity decreased but remained significant $\left(\mathrm{I}^{2}=89.1 \%, \tau^{2}=0.005, \mathrm{Q}_{\text {resid }}(2)=23.1, p<0.0001\right)$ (Figure S2). Regarding Mason et al. [16], the removal of this study decreased the pooled prevalence rate to $16.7 \%$, whilst the heterogeneity between studies remained significantly high $\left(\mathrm{I}^{2}=95 \%, \tau^{2}=0.007, \mathrm{Q}_{\text {resid }}(2)=47.2, p<0.0001\right)$ (Figure $\left.\mathrm{S} 2\right)$.

The point prevalence rate of PTSD was 30.4 (95\% CI: 11.7-49.1) (Figure 4), which was higher than comparable prevalence rates for depression and anxiety. The heterogeneity between studies was also the highest amongst studies that measured PTSD: $\mathrm{I}^{2}=99 \%, \tau^{2}=0.0355, \mathrm{Q}_{\text {resid }}(3)=210.9$, $p<0.01$ (Figure 4). 
Study

Graham et al. 2019

Munro et al 2017

Mason et al. 2010

French et al. 2019
Cases Total Prevalence

$\begin{array}{rr}25 & 354 \\ 214 & 605 \\ 104 & 288 \\ 49 & 112\end{array}$

7.06 [ 4.39; 9.73]

$35.37[31.56 ; 39.18]$

$36.11[30.56 ; 41.66]$

$43.75[34.56 ; 52.94]$

Random effects model

Heterogeneity: $I^{2}=99 \%, \tau^{2}=0.0355, \chi_{3}^{2}=210.86(p<0.01)$

$95 \%$ C.I.

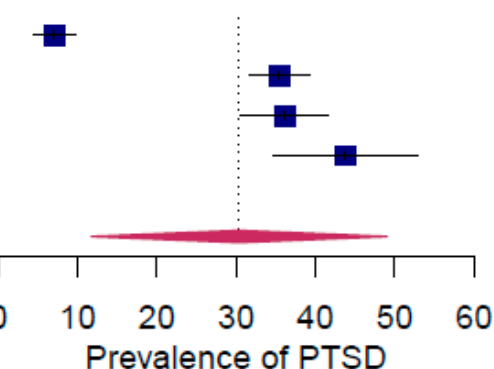

Figure 4. Forest plot of the prevalence rate of Post-Traumatic Syndrome Disorder (PTSD).

In the sensitivity analysis, the study by Graham et al. [15] was again identified as an outlier, having a significant influence on the effect size (Figure S3). By removing that study, the prevalence of PTSD increased to $36 \%$ and the effect size heterogeneity decreased significantly $\left(\mathrm{I}^{2}=0.01 \%, \tau^{2}=0.000\right.$, $\mathrm{Q}_{\text {resid }}(2)=2.7, p=0.3$ ).

Beggs' tests of funnel asymmetry for anxiety, depression and PTSD were non-significant $(p>0.05)$, which indicated no publication bias.

\section{Discussion}

The point prevalence of common mental health problems was high in populations exposed to floods in the UK. The impact of the floods led to short-term and long-term mental health problems and contributed to additional problems such as the use of alcohol and prescription drugs and increased healthcare resource use among those affected. Critical features of the floods associated with mental health problems were water depth and absence of flood warning. Secondary stressors that characterized responses to flooding included evacuation and displacement and disruption to services and amenities and an absence of post-flood support. There was modest evidence of heightened resilience and no greater risk of mental health problems in populations exposed to repeat flooding compared with single flooding. Social and economic inequalities were also evident. Women experienced a greater mental health impact than men, as did people who rent rather than own their home, and in the one study that included ethnicity, there was a greater risk among those from a minority ethnic community.

The observed prevalence rate of PTSD among populations exposed to flooding in the studies included in this review (30.4\%) is substantially higher than the lifetime prevalence rate of $7.8 \%$ observed in the general population [43] (Table 2). The lifetime prevalence rate for major depressive disorder in the general population has increased over the past 25 years and is estimated to be $20.6 \%$, which is comparable with the prevalence rate for depression identified in this review (21.4\%) [44] (Table 2). Generalized anxiety disorder is a relatively common disorder with a 12-month prevalence of $3.1 \%$ and a lifetime prevalence of $5.7 \%$. We found a very high prevalence rate for anxiety $(19.8 \%)$ in the included studies, suggesting that reports of anxiety also overlapped with reports of anxiety disorders as a whole, which have a lifetime prevalence of $28.8 \%$ [45] (Table 2). As reported in the Results section, the study by Graham et al. [15] was an outlier to the other studies regarding the impact of flooding on the prevalence of anxiety, depression and PTSD. Graham et al. [15] based their analysis on a stratified sample of the UK population, that was not specifically related to a flooding event. In contrast, the other three studies reported in Figures 2-4 were conducted in geographical areas where severe flooding had occurred or with groups of individuals who had been exposed directly to flooding. In the Graham et al. [15] study, severe flood damage (having to leave the home for at least three days, or being unable to leave the home for at least three days) was recorded by only seven out of 7525 participants. The equivalent figures are 449 of 2126 respondents for the Munro et al. [27] study and 269 or 444 responses for the Mason et al. [16] study. An additional reason for the difference observed is likely to be because the Graham et al. [15] study related to "storm and flood-related damage", and not only flood damage. Based on insurance 
claims data, floods represent $19 \%$ of the overall storm- and flood-related damage [15]. Although the costs of flood-related claims are $>3.5$ times higher than other storm damage [15] and may be expected to lead to higher mental health impacts relative to other storm damage, the overall prevalence of anxiety, depression and PTSD reported by Graham et al. [15] would therefore be expected to be lower.

Table 2. Mental health morbidity prevalence for population exposed to flooding and general population for anxiety, depression and post-traumatic stress disorder (PTSD).

\begin{tabular}{ccc}
\hline Mental Health Morbidity & $\begin{array}{c}\text { Prevalence in Population } \\
\text { Exposed to Flooding (\%) }\end{array}$ & $\begin{array}{c}\text { Prevalence in General } \\
\text { Population (\%) }\end{array}$ \\
\hline Anxiety & 19.8 & 5.7 \\
Depression & 21.4 & 20.6 \\
PTSD & 30.4 & 7.8 \\
\hline
\end{tabular}

When compared with international evidence about the impact of flooding, we see that the prevalence rates identified in our review compare with those reported for depression (17.2\%) and PTSD $(22.4 \%)$ in the aftermath of floods in South Korea [46]. Much lower prevalence rates for PTSD were reported in a retrospective study of flooding in Hunan, China, although in keeping with our findings, this study reported that flood severity and female sex were associated with higher odds of PTSD [47].

Significantly, the level of mental health problems observed among flood victims compares with those observed among displaced populations in conflict zones [48]. Displacement and loss of a sense of place and home were major themes that underscored reports of common mental health problems among flooded populations. This was true even one year after flooding, which suggests that displacement is an important secondary stressor that drives longer term mental health outcomes after flooding. The loss of a sense of place that stemmed from displacement relates to the concept of place attachment, which is a concept that describes the psychological and emotional bonds between people and places [49]. Disruption to these bonds can lead to solastalgia, which refers to distress caused by environmental degradation and loss of home and belongings. Moreover, as reported in the narrative synthesis, a breakdown in social ties and community spirit were also associated with displacement and disruption to a sense of place, highlighting the importance of social capital for the maintenance of well-being [38].

\subsection{Implications for Research and Policy}

Improving the early identification of mental health problems and increasing access to treatment is a global public health priority in the context of natural disasters such as flooding. While there are existing evidence-based psychological therapies recommended for managing depression and anxiety, such approaches are typically only made available to clinical populations with above-threshold symptoms. In the context of flooded populations, there is a need to consider how best to provide appropriate and effective psychological care at scale for people with a broader range of mental health symptoms. Furthermore, there is a case to consider preventive approaches that build resilience in communities at risk of flooding. There is no strong evidence that psychological de-briefing is effective in disaster contexts and this approach is not warranted [50]. However there is a growing understanding that help-seeking for mental health might be encouraged by greater community mental health literacy and the influence of social networks [51]. Mental health literacy refers to knowledge and beliefs about mental health which can aid the recognition, management and prevention of mental health difficulties. In view of this, mental health first aid is designed to increase knowledge about common mental health problems and reduce stigma and provide the means to offer immediate help and signpost to professional services. There is modest evidence that mental health first aid is associated with small to medium effects for improving knowledge about attitudes towards mental health and to promote help-seeking behavior [52]. Furthermore, there is emerging evidence that mental health first aid can improve mental health literacy and facilitate appropriate support for people with mental health problems [53], suggesting that populations at risk from flooding would benefit from the roll out of 
such programmes. However, formal evaluation of mental health first aid is scarce and more robust assessments are needed to help make evidence-based decisions about its potential effectiveness and implementation [54].

More broadly, there is scant evidence about the effectiveness of acute psychological interventions for disaster-related mental health problems. There are calls within psychiatry to heed a warning about reducing trauma to a formula about exposure and treatment and instead see disaster-related trauma as intertwined within the more complex context of pre-existing and comorbid mental health problems, including exposure to previous traumatic events [55]. This calls for novel approaches that draw on systems thinking that can propose integrated solutions to address the connections between climate change and climate mitigation and the persistent social determinants of mental ill health [56]. Here the role of interventions that can enhance community and environmental resilience, including improved risk communication [57] and explicitly incorporating flood risk and management into urban planning [58] could be key to addressing the mental health challenges posed by climate change in the 21st century.

The findings have implications for local authorities and national governments alike. They imply that steps to reduce the risk of climate-related disasters will have long-term benefits to the public purse and society more widely by reducing the risk of long-term mental ill health in communities. Mental ill health carries a heavy cost for individuals, families and communities, and actions to prevent it can present good value for money. As well as taking action to reduce the risk of climate-related disasters, local authorities can also take steps to build community resources and resilience, especially among the most marginalized and disadvantaged social groups [59].

The findings also have significance for resource allocation and planning of mental health services. Flooding, and potentially other climate-related disasters, increase a community's risk of mental ill health. Localities that have experienced or face a high risk of flooding may need more investment in psychological support, and this will be needed in the long-term, and not just in the form of a crisis response.

This paper also identifies some major gaps in research that need to be addressed if we are to build resilience against the psychological impacts of climate disasters. While we were able to draw conclusions about the impacts of flooding, there is insufficient evidence relating to other types of incidents, including heatwaves. Additionally, we found that people from more deprived backgrounds who rented property had poorer psychological health after flooding. Future qualitative research could address questions about the differential impact of flooding among populations in relation to income, home ownership and ethnicity.

\subsection{Strengths and Limitations}

A strength of this review is that we included studies that included reports of common mental health problems and not just PTSD, making it a comprehensive assessment of the prevalence of mental ill health in flood-exposed populations in the UK. Furthermore, we only included studies that identified populations with identifiable mental health problems that map to valid diagnoses, thereby enabling a comparison of our findings with wider epidemiological evidence about mental health in the general population. Our review also included studies on the impact of fluvial flooding, which is the most common form of flooding in the UK, making it more policy-relevant for the UK and other contexts where this form of flooding poses the greatest threat. By including a qualitative narrative synthesis, we were also able to highlight contextual factors that underpinned the onset and maintenance of mental health problems among flood victims.

Our review has a number of limitations. First, while our review offers a comprehensive assessment of the impact of flooding on mental health, our search only identified a single study that addressed the mental health impact of other climate change extreme weather events (heat waves). However, by focusing on the impact of fluvial flooding and heat waves, our review provides a strong signal for further research about the mitigation of the impact of extreme weather events most likely to affect the 
UK. Secondly, we included in the meta-analysis studies that reported both short-term ( $<6$ months) and longer-term (between 6 and 12 months) mental health outcomes and we were unable to differentiate between the direct and indirect effects of flooding on mental health. As indicated by the qualitative synthesis, the role of secondary stressors is especially important in understanding how interventions might mitigate and manage the longer-term mental health impact on communities affected by floods. Thirdly, most included studies were uncontrolled, and it was not possible to ascertain the comparative prevalence of mental health problems in unexposed populations. Finally, the included studies displayed high levels of heterogeneity in terms of type of flood and flood severity and meta-analysis of these studies precluded the means to disentangle the impact of these factors on the prevalence of mental health problems.

\section{Conclusions}

This systematic review showed that populations exposed to floods have a high prevalence of common mental health problems, with the rate for PTSD and anxiety disorders exceeding lifetime prevalence rates in the general population. Mental health problems were especially attributable to displacement and loss of sense of place and home and disturbances to social capital, and they affect those with the least resources disproportionately. Climate change has significantly increased the prospect of more frequent extreme weather events and there is an urgency to develop solutions to support people's short- and long-term mental health following events such as floods. There is scope for more research that can address how to mitigate the risk associated with extreme weather events and build resilience within communities affected by floods.

Supplementary Materials: The following are available online at http://www.mdpi.com/1660-4601/17/22/8581/s1, Table S1: PRISMA 2009 checklist, Table S2: Full search strategy, Figure S1: Forest plot of the leave one out sensitivity analysis for anxiety, Figure S2: Forest plot of the leave one out sensitivity analysis for depression, Figure S3: Forest plot of the leave one out sensitivity analysis for Post-Traumatic Syndrome Disorder (PTSD).

Author Contributions: P.C.L.W. and A.B. conceived the study; J.C., P.C.L.W. and P.A.C. designed the study. J.C. undertook the literature searches, screened database searches, extracted and analyzed the data. P.A.C. and J.C. wrote the first draft of the paper; J.C., P.C.L.W., A.B. and P.A.C. revised the manuscript for critical intellectual content and approved the final version. All authors have read and agreed to the published version of the manuscripts.

Funding: This work is supported by UK Research and Innovation Closing the Gap Network+ (ES/S004459/1). UKRI does not necessarily endorse the view expressed by the authors.

Conflicts of Interest: The authors declare no conflict of interest. The funders had no role in the design of the study; in the collection, analyses, or interpretation of data; in the writing of the manuscript, or in the decision to publish the results.

\section{References}

1. Whitmee, S.; Haines, A.; Beyrer, C.; Boltz, F.; Capon, A.G.; de Souza Dias, B.F.; Ezeh, A.; Frumkin, H.; Gong, P.; Head, P.; et al. Safeguarding human health in the Anthropocene epoch: Report of The Rockefeller Foundation-Lancet Commission on planetary health. Lancet 2015, 386, 1973-2028. [CrossRef]

2. Elsner, J.B. Continued increases in the intensity of strong tropical cyclones. Bull. Am. Meteorol. Soc. 2020. [CrossRef]

3. EASAC. Extreme Weather Events in Europe: Preparing for Climate Change Adaptation: An Update on EASAC'S 2013 Study; European Academies' Science Advisory Council: Brussels, Belgium, 2018.

4. Guerreiro, S.B.; Dawson, R.J.; Kilsby, C.; Lewis, E.; Ford, A. Future heat-waves, droughts and floods in 571 European cities. Environ. Res. Lett. 2018, 13, 034009. [CrossRef]

5. McMichael, A.J.; Woodruff, R.E.; Hales, S. Climate change and human health: Present and future risks. Lancet 2006, 367, 859-869. [CrossRef]

6. IPCC. Climate Change 2014: Impacts, Adaptation, and Vulnerability. Contribution of Working Group II to the Fifth Assessment Report of the Intergovernmental Panel on Climate Change; Cambridge University Press: Cambridge, UK, 2014. 
7. Clayton, S.; Devine-Wright, P.; Stern, P.C.; Whitmarsh, L.; Carrico, A.; Steg, L.; Swim, J.; Bonnes, M. Psychological research and global climate change. Nat. Clim. Chang. 2015, 5, 640-646. [CrossRef]

8. Hoegh-Guldberg, O.; Jacob, D.; Bindi, M.; Brown, S.; Camilloni, I.; Diedhiou, A.; Djalante, R.; Ebi, K.; Engelbrecht, F.; Guiot, J. Global warming of $1.5^{\circ} \mathrm{C}$. In An IPCC Special Report on the Impacts of Global Warming of $1.5^{\circ} \mathrm{C}$ above Pre-Industrial Levels and Related Global Greenhouse Gas Emission Pathways, in the Context of Strengthening the Global Response to the Threat of Climate Change, Sustainable Development, and Efforts to Eradicate Poverty; Masson-Delmotte, V., Pörtner, H.O., Eds.; Cambridge University Press: Cambridge, UK, 2018; pp. 175-311.

9. Palinkas, L.A.; Wong, M. Global climate change and mental health. Curr. Opin. Psychol. 2020, 32, 12-16. [CrossRef]

10. Haines, A.; Kovats, R.S.; Campbell-Lendrum, D.; Corvalan, C. Climate change and human health: Impacts, vulnerability, and mitigation. Lancet 2006, 367, 2101-2109. [CrossRef]

11. James, S.L.; Abate, D.; Abate, K.H.; Abay, S.M.; Abbafati, C.; Abbasi, N.; Abbastabar, H.; Abd-Allah, F.; Abdela, J.; Abdelalim, A.; et al. Global, regional, and national incidence, prevalence, and years lived with disability for 354 diseases and injuries for 195 countries and territories, 1990-2017: A systematic analysis for the Global Burden of Disease Study 2017. Lancet 2018, 392, 1789-1858. [CrossRef]

12. Chisholm, D.; Sweeny, K.; Sheehan, P.; Rasmussen, B.; Smit, F.; Cuijpers, P.; Saxena, S. Scaling-up treatment of depression and anxiety: A global return on investment analysis. Lancet Psychiatry 2016, 3, 415-424. [CrossRef]

13. Office for National Statistics. Sickness absence in the labour market: 2018. Analysis describing sickness absence rates of workers in the UK labour market; Office for National Statistics: London, UK, 2018.

14. O'Shea, N.; Bell, A. A Spending Review for Wellbeing-Briefing; Centre for Mental health: London, UK, 2020.

15. Graham, H.; White, P.; Cotton, J.; McManus, S. Flood- and weather-damaged homes and mental health: An analysis using England's Mental Health Survey. Int. J. Environ. Res. Public Health 2019, 16, 3256. [CrossRef]

16. Mason, V.; Andrews, H.; Upton, D. The psychological impact of exposure to floods. Psychol. Health Med. 2010, 15, 61-73. [CrossRef] [PubMed]

17. ASC UK. Climate Change Risk Assessment 2017 Synthesis Report: Priorities for the Next Five Years; Adaptation Sub-Committee of the Committee on Climate Change: London, UK, 2016.

18. Moher, D.; Liberati, A.; Tetzlaff, J.; Altman, D.G. Preferred reporting items for systematic reviews and meta-analyses: The PRISMA statement. BMJ 2009, 339, b2535. [CrossRef] [PubMed]

19. Stephenson, D.B.; Diaz, H.; Murnane, R. Definition, diagnosis, and origin of extreme weather and climate events. In Climate extremes and society; Diaz, H.F., Murnane, R.J., Eds.; Cambridge University Press: Cambridge, UK, 2008; Volume 340, pp. 11-23.

20. World Health Organization (WHO). International Statistical Classification of Diseases and Related Health Problems (ICD-10); 10th Revision; WHO: Geneva, Switzerland, 1992.

21. Loney, P.L.; Chambers, L.W.; Bennett, K.J.; Roberts, J.G.; Stratford, P.W. Critical appraisal of the health research literature: Prevalence or incidence of a health problem. Chronic Dis. Can. 1998, 19, 170-176. [PubMed]

22. Mays, N.; Pope, C.; Popay, J. Systematically reviewing qualitative and quantitative evidence to inform management and policy-making in the health field. J. Health Serv. Res. Policy 2005, 10, 6-20. [CrossRef]

23. Higgins, J.P.T.; Thompson, S.G.; Deeks, J.J.; Altman, D.G. Measuring inconsistency in meta-analyses. BMJ 2003, 327, 557-560. [CrossRef]

24. Wang, N. Conducting Meta-Analyses of Proportions in R; Research Gate: College Station, TX, USA, 2017.

25. R Core Team. R: A Language and Environment for Statistical Computing; R Foundation for Statistical Computing: Vienna, Austria, 2019.

26. French, C.E.; Waite, T.D.; Armstrong, B.; Rubin, G.J.; Beck, C.R.; Oliver, I. Impact of repeat flooding on mental health and health-related quality of life: A cross-sectional analysis of the English National Study of Flooding and Health. BMJ Open 2019, 9, e031562. [CrossRef]

27. Munro, A.; Kovats, R.S.; Rubin, G.J.; Waite, T.D.; Bone, A.; Armstrong, B.; Beck, C.R.; Amlot, R.; Leonardi, G.; Oliver, I. Effect of evacuation and displacement on the association between flooding and mental health outcomes: A cross-sectional analysis of UK survey data. Lancet Planet. Health 2017, 1, e134-e141. [CrossRef]

28. Jermacane, D.; Waite, T.D.; Beck, C.R.; Bone, A.; Amlot, R.; Reacher, M.; Kovats, S.; Armstrong, B.; Leonardi, G.; James Rubin, G.; et al. The English National Cohort Study of Flooding and Health: The change in the prevalence of psychological morbidity at year two. BMC Public Health 2018, 18, 330. [CrossRef] 
29. Tunstall, S.; Tapsell, S.; Green, C.; Floyd, P.; George, C. The health effects of flooding: Social research results from England and Wales. J. Water Health 2006, 4, 365-380. [CrossRef]

30. Reacher, M.; McKenzie, K.; Lane, C.; Nichols, T.; Kedge, I.; Iversen, A.; Hepple, P.; Walter, T.; Laxton, C.; Simpson, J. Health impacts of flooding in Lewes: A comparison of reported gastrointestinal and other illness and mental health in flooded and non-flooded households. Comm. Dis. Publ. Health 2004, 7, 39-46.

31. Paranjothy, S.; Gallacher, J.; Amlot, R.; Rubin, G.J.; Page, L.; Baxter, T.; Wight, J.; Kirrage, D.; McNaught, R.; Palmer, S.R. Psychosocial impact of the summer 2007 floods in England. BMC Public Health 2011, 11, 145. [CrossRef] [PubMed]

32. Tempest, E.L.; Carter, B.; Beck, C.R.; Rubin, G.J.; English Natl Study Flooding, H. Secondary stressors are associated with probable psychological morbidity after flooding: A cross-sectional analysis. Eur. J. Public Health 2017, 27, 1042-1047. [CrossRef] [PubMed]

33. Waite, T.D.; Chaintarli, K.; Beck, C.R.; Bone, A.; Amlot, R.; Kovats, S.; Reacher, M.; Armstrong, B.; Leonardi, G.; Rubin, G.J.; et al. The English national cohort study of flooding and health: Cross-sectional analysis of mental health outcomes at year one. BMC Public Health 2017, 17, 129. [CrossRef] [PubMed]

34. Greene, G.; Paranjothy, S.; Palmer, S.R. Resilience and Vulnerability to the Psychological Harm from Flooding: The Role of Social Cohesion. Am. J. Public Health 2015, 105, 1792-1795. [CrossRef] [PubMed]

35. Bennet, G. Bristol floods 1968. Controlled survey of effects on health of local community disaster. Br. Med. J. 1970, 3, 454-458. [CrossRef] [PubMed]

36. Tapsell, S.M.; Tunstall, S.M. "I wish I'd never heard of Banbury": The relationship between 'place' and the health impacts from flooding. Health Place 2008, 14, 133-154. [CrossRef]

37. Akerkar, S.; Fordham, M. Gender, place and mental health recovery in disasters: Addressing issues of equality and difference. Int. J. Disaster Risk Reduct 2017, 23, 218-230. [CrossRef]

38. Wind, T.R.; Komproe, I.H. The mechanisms that associate community social capital with post-disaster mental health: A multilevel model. Soc. Sci. Med. 2012, 75, 1715-1720. [CrossRef]

39. Milojevic, A.; Armstrong, B.; Wilkinson, P. Mental health impacts of flooding: A controlled interrupted time series analysis of prescribing data in England. J. Epidemiol. Community Health 2017, 71, 970-973. [CrossRef]

40. Page, L.A.; Hajat, S.; Kovats, R.S. Relationship between daily suicide counts and temperature in England and Wales. Br. J. Psychiatry 2007, 191, 106-112. [CrossRef]

41. Lamond, J.E.; Joseph, R.D.; Proverbs, D.G. An exploration of factors affecting the long term psychological impact and deterioration of mental health in flooded households. Environ. Res. 2015, 140, 325-334. [CrossRef] [PubMed]

42. Tapsell, S. The hidden impacts of flooding: Experiences from two English communities. In Water Resources Management; Marino, M.A., Simonovic, S.P., Eds.; IAHS Press: Wallingford, UK, 2001; pp. 319-324.

43. Kessler, R.C.; Chiu, W.T.; Demler, O.; Merikangas, K.R.; Walters, E.E. Prevalence, severity, and comorbidity of 12-month DSM-IV disorders in the National Comorbidity Survey Replication. Arch. Gen. Psychiatry 2005, 62, 617-627. [CrossRef] [PubMed]

44. Hasin, D.S.; Sarvet, A.L.; Meyers, J.L.; Saha, T.D.; Ruan, W.J.; Stohl, M.; Grant, B.F. Epidemiology of Adult DSM-5 Major Depressive Disorder and Its Specifiers in the United States. JAMA Psychiatry 2018, 75, 336-346. [CrossRef] [PubMed]

45. Kessler, R.C.; Berglund, P.; Demler, O.; Jin, R.; Merikangas, K.R.; Walters, E.E. Lifetime prevalence and age-of-onset distributions of DSM-IV disorders in the National Comorbidity Survey Replication. Arch. Gen. Psychiatry 2005, 62, 593-602. [CrossRef]

46. Heo, J.H.; Kim, M.H.; Koh, S.B.; Noh, S.; Park, J.H.; Ahn, J.S.; Park, K.C.; Shin, J.; Min, S. A prospective study on changes in health status following flood disaster. Psychiatry Investig. 2008, 5, 186-192. [CrossRef]

47. Liu, A.; Tan, H.; Zhou, J.; Li, S.; Yang, T.; Wang, J.; Liu, J.; Tang, X.; Sun, Z.; Wen, S.W. An epidemiologic study of posttraumatic stress disorder in flood victims in Hunan China. Can. J. Psychiatry 2006, 51, 350-354. [CrossRef]

48. Charlson, F.; van Ommeren, M.; Flaxman, A.; Cornett, J.; Whiteford, H.; Saxena, S. New WHO prevalence estimates of mental disorders in conflict settings: A systematic review and meta-analysis. Lancet 2019, 394, 240-248. [CrossRef]

49. Stedman, R.C. Toward a Social Psychology of Place:Predicting Behavior from Place-Based Cognitions, Attitude, and Identity. Environ. Behav. 2002, 34, 561-581. [CrossRef] 
50. Rose, S.; Bisson, J.; Churchill, R.; Wessely, S. Psychological debriefing for preventing post traumatic stress disorder (PTSD). Cochrane Database Syst. Rev. 2002, CD000560. [CrossRef]

51. Suka, M.; Yamauchi, T.; Sugimori, H. Help-seeking intentions for early signs of mental illness and their associated factors: Comparison across four kinds of health problems. BMC Public Health 2016, 16, 301. [CrossRef]

52. Hadlaczky, G.; Hokby, S.; Mkrtchian, A.; Carli, V.; Wasserman, D. Mental Health First Aid is an effective public health intervention for improving knowledge, attitudes, and behaviour: A meta-analysis. Int. Rev. Psychiatry 2014, 26, 467-475. [CrossRef] [PubMed]

53. Morgan, A.J.; Ross, A.; Reavley, N.J. Systematic review and meta-analysis of Mental Health First Aid training: Effects on knowledge, stigma, and helping behaviour. PLoS ONE 2018, 13, e0197102. [CrossRef] [PubMed]

54. Richardson, R.; Dale, H.E.; Wellby, G.; McMillan, D.; Churchill, R. Mental Health First Aid as a tool for improving mental health and well-being. Cochrane Database Syst. Rev. 2018. [CrossRef]

55. The Lancet Psychiatry. Send in the therapists? Lancet Psychiatry 2020, 7, 291. [CrossRef]

56. Berry, H.L.; Waite, T.D.; Dear, K.B.G.; Capon, A.G.; Murray, V. The case for systems thinking about climate change and mental health. Nat. Clim. Change 2018, 8, 282-290. [CrossRef]

57. Bradford, R.A.; O'Sullivan, J.J.; van der Craats, I.M.; Krywkow, J.; Rotko, P.; Aaltonen, J.; Bonaiuto, M.; De Dominicis, S.; Waylen, K.; Schelfaut, K. Risk perception-issues for flood management in Europe. Nat. Hazard Earth Sys. Sci. 2012, 12, 2299-2309. [CrossRef]

58. Zevenbergen, C.; Veerbeek, W.; Gersonius, B.; van Herk, S. Challenges in urban flood management: Travelling across spatial and temporal scales. J. Flood Risk Manag. 2008, 1, 81-88. [CrossRef]

59. Allwood, L. Our Place: Local Authorities and the Public's Mental Health; Centre for Mental Health: London, UK, 2020.

Publisher's Note: MDPI stays neutral with regard to jurisdictional claims in published maps and institutional affiliations. 